\title{
Tasks of safety education institutions concerning the needs of state security
}

\section{KEYWORDS}

education for safety, education, J.A. principles of John Amos Comenius, John Locke, Immanuel Kant

\begin{abstract}
Martuszewska Jolanta, Tasks of safety education institutions concerning the needs of state security. Culture - Society Education no. 1(17) 2020, Poznań 2020, pp. 411-421, Adam Mickiewicz University Press. ISSN 2300-0422. DOI 10.14746/kse.2020.17.15.2
\end{abstract}

The desire to live a safe life is one of the most important human needs, while education is the basis of knowledge of the society as a whole. To ensure the safety of the individual and the security of the state, there is a need for stable cooperation between various security institutions. There are many safety education institutions that work for the needs of state security. These include the Education for Safety Bureau, the post of Education for Safety Inspector, the post of School Safety Coordinator, School Safety Clubs, etc.

The aim of this paper is to describe the situation in education based on safety education teaching in the 21st century. Other objectives include indicating tasks and rational solutions in education on the basis of the principles introduced by scholars, such as J.A. Comenius, J. Locke, I. Kant, which remain valid to this day.

\section{Introduction}

Safety is a state of an absence of danger, a state of peace and security. It concerns every person, group of people, nation, object, region or state. It is an inalienable

\footnotetext{
* ORCID https://orcid.org/0000-0002-6386-9534.
} 
and non-transferable, crucial, vital and indispensable value. As a fundamental value, it takes one of the highest positions in the axiological hierarchy.

People do not value safety in itself - they do it because it provides and guarantees them with other valuable values and is a means to achieve or maintain other values such as life, health, success, property, acquired rights and benefits, etc.

The sense of security is subjective and it means not feeling threatened or afraid. However, it should be noted that a belief or conviction is not an evidence of existence of a given thing. The opposite word for safety is danger or threat. To threaten stands for cause (someone or something) to be vulnerable or at risk; endanger.

The threat may concern people, their health, safety, existence, happiness, material things, possessions, equipment, buildings, cities, regions, countries (...), but also water, food, atmosphere, animals, all nature, and even space. (Doroszewski, 2009). Depending on the individual situation in which people end up, different factors may cause a state of threat and a feeling of uncertainty, but they do not affect knowledge. Thus, people are going to articulate their needs regarding the right to safety in different ways.

Safety is associated with an existing threat. Everyone experiences the sense of threat in a different way and has a different understanding of (un)certainty. On the other hand, everyone should be aware of the risks, ways to avoid them and alleviate their impact.

The responsibility for the state of security rests with the government and the institutions established for the purpose of ensuring it. It should be noted that the sense of safety is determined by factors, which are both objective and measurable, as well as subjective, difficult to measure and not always rational (Doroszewski, 2009).

Ensuring safety involves the need to use a variety of tools. These include, among others:

- state and local government bodies;

- diplomatic and consular authorities;

- forces and services of the military;

- NGOs.

Other relevant issues concern the quality of power, state policy, morale of the nation, the condition and observance of state law, the level of national culture, science, education, etc.

The national security policy is made up of both theory and practice of security. Both these areas concern the ways of conscious influence of the state on the environment and its security by means of specific tools (instruments) and measures, in order to achieve the objectives set by the subjects of the national security policy. 
The development of a properly organised state security system is a fundamental objective of Polish security policy. (...) the establishment and implementation of this policy should involve rather wide circles of our society. It is particularly important to join forces of the local administration and the local communities, since the residents of municipalities and their authorities put the objectives of security policy into practice. (National Security Strategy, 2014: 36; Bożek: 281-312)

In order to strengthen and shape the desired state of security for the performance of their tasks, specialised institutions and services are established, which within the framework of their competencies - are held responsible for the various areas of security, monitoring its status and act accordingly to the results of said monitoring.

\section{Education for safety - tasks, objectives, challenges}

The primary concern for safety is the human being, protecting their life and health, property and the environment in which they live, study and work. State security policy should therefore be focused on these issues. Ensuring people's safety is the essence of national security. The concept of security envisioned in this manner is a prerequisite for the harmonious functioning of individuals and their development, which translates into the development and functioning of local groups, societies (nations) and - indirectly - also the international community. It should be pointed out that without a sense of individual security, it is impossible for an individual to progress and develop socially.

Even in the Antique period, two tendencies related to the safety education emerged. The first one concerned properly preparing soldiers for the battle, while the other concerned general civic defence activities. These roles were implemented in various forms.

Immanuel Kant compares the Enlightenment to reaching maturity. He believes that is associated with the lack of ability to use reason and resorting to following others' guidance (Kupś, 2005: 44-45; Szymaniec, 2009). On the other hand, he stresses that it is convenient to look for excuses instead of taking action on one's own (Kupś, 2005: 48-49). A practical approach to the subject of local threats, such as electricity, water and gas supply failures, will allow for presenting a certain scheme of conduct to know how to behave in case of such a situation.

Local institutions should break the mould of regulations and bureaucracy, while addressing various issues boldly and creatively in cooperation with schools and residents, so that the subject of threats becomes known to everybody, including the elderly. Exercises with practitioners and specialists will help raise awareness 
of certain situations among the general populace, such as being a first responder in life threatening situations, as well as train them in practice.

According to the philosopher, the state is a "sensible institution", following moral principles and values. What is more, as a strong entity, the state takes care of its vital interests and existence (Grabowska, 2011: 235-248). In the early stages of education, it has a duty to educate young people and to shape their system of values, orienting it towards the individual, the nation and the state.

According to John Locke, a human being is a rational being (Grabowska, 2011: 243). Being rational enables the independence of the mind and is closely linked to freedom. The philosopher argues that proper education is indispensable in this regard. He points out that since the body can be shaped through exercises, reason can also be susceptible to such activities. (Locke, 1969: 608) When reason guides our actions, it restrains our instincts and passions, leading us to do better use of our freedom. Practical exercises and the contents of the core curriculum of the education for safety subject should be carried out in equal proportions.

Without reason, freedom becomes dangerous. However, a human being with the right to choose can choose wrong. All the errors made in this way result from insufficient skills of using reason, especially from a too fast transition to action. (Grabowska, 2011: 245)

Therefore, by exercising the reason (which is the task of the school, teacher, and student), the dangers of freedom can be minimised. It is important to develop mental abilities in harmony with reason. The school's task is therefore to ensure that the education process goes on in a proper way.

In Some Thoughts Concerning Education (Locke, 1959: 205), the philosopher presents an educational curriculum for future gentlemen. Its aim is the comprehensive mental and physical development of the pupils, who are to become capable of serving the country. The most important goal of upbringing turns out to be achieving a state, in which the reason guides their choices and subsequent actions to the greatest extent possible. Being rational, self-confident and decisive, for example in situations where human life is in danger, is a crucial skill.

The instruments that ensure social and political agreement on security issues are civic education, social dialogue, parliamentary cooperation and the National Security Council. (National Security Strategy, 2014: 25) On the other hand,

(...) social potential, including human capital, is an important factor determining the growth of the national economy, the efficiency of the state, the activity of civil society and the general improvement of the quality of life of citizens. A modern system of public and 
higher education, as well as the spread of various forms of lifelong learning serve to educate an active and mobile society. Safety education is an important element in the development of human and social capital. (National Security Strategy, 2014: 14)

Therefore, the social potential determines the efficiency of the state, as well as the activity of civil society. Education for safety as a school subject can be an indispensable element in preserving the stability of the state by preparing young people to prevent and combat threats.

The task of education for safety is to disseminate knowledge about the safety of the citizens in their local environment (National Security Strategy, 2014: 39). The priority is to raise public awareness of the understanding of threats to their security and the development of competences to respond to them in a targeted and rational manner. The educational goal of teachers should be not so much to equip students with knowledge, but to apply said knowledge in practice. It is important to increase the effectiveness of the public administration in security matters through continuous improvement of qualifications and ability to effectively respond to threats.

Improving the competences of education for safety in the area of security requires intensification and better coordination. It is important to continuously improve the quality of education in the general education system, higher education and in-service training of soldiers, officers, civilian personnel of the military and uniformed services, public administration employees and teachers of the subject of education for security, which affects the security of the state (National Security Strategy of the Republic of Poland, 2014: 52).

It is implemented by general and higher education, central and local state institutions, associations and NGOs.

\section{School education in the 21 st century}

The primary function of schools, in addition to the care of the children entrusted to them, is defined as upbringing, which involves shaping attitudes, as well as teaching, the aim of which should be the transfer of knowledge and training skills. (Kmita, 1991) Education is the foundation of development, while progress and quality of life will increasingly depend on society's knowledge and ability to use it.

It is important to increase students' awareness of various dangers and threats by intensifying educational activities at all levels of education, as well as through training and social campaigns. Therefore, education should adapt to changing 
realities and introduce innovative changes. The school needs changes, because according to the Report on Citizens' Consultations on Education (2019: 18-28) -

1) the skills and attitudes acquired hardly lead to shaping and development through practical activities and experience;

2) it provides students with too much theoretical knowledge at the expense of other functions. The knowledge offered at school is often described as "superfluous", "encyclopaedic" or simply "trivia";

3) insufficient practical knowledge and competences for further life are taught in the curriculum. It is important that school develops the so-called soft skills of students, which refer to life skills, understood as the ability to adapt, as well as positive behaviours, enabling the individual to deal effectively with the requirements and challenges of everyday life." (WHO, 1994). These skills enable the student to properly use the acquired theoretical knowledge, providing them with the ability to think creatively, filter information and learn independently. This is essential for proper functioning in modern society;

4) apart from developing a civic attitude, the school does not reinforce student's attitudes concerning solidarity, especially intergenerational skills, attitudes and empathy.

Table 1. How does school teach and educate? How does it motivate students to learn? What experience does it provide?

\begin{tabular}{|c|c|}
\hline & \\
\hline $\begin{array}{l}\text { - doesn't teach thinking, } \\
\text { - too much subjects in the curriculum, } \\
\text { - the way of conveying difficult content is not ap- } \\
\text { propriate to the age of the child, } \\
\text { - too much tests, diagnosis, } \\
\text { - imbalanced level, } \\
\text { - not enough contact with the student, } \\
\text { - prepares for the exams, } \\
\text { - lonely: no support from the authorities, local } \\
\text { governments, } \\
\text { - divided into stages, } \\
\text { - the examination system makes teachers ac- } \\
\text { countable to their parents primarily for exami- } \\
\text { nation results, } \\
\text { - no relationship/dialogue, } \\
\text { - pressure for success and educational added } \\
\text { value, } \\
\text { - too many documents, } \\
\text { - tools instead of goals, } \\
\text { - the same teaching method, }\end{array}$ & $\begin{array}{l}\text { - diagnosis is a hint for the student, teacher, par- } \\
\text { ents, } \\
\text { - positive motivation, } \\
\text { - increasing teacher-student interaction, } \\
\text { - practical learning with references to real-life sce- } \\
\text { narios, } \\
\text { - learning to think logically, } \\
\text { - diversity of teaching methods, } \\
\text { - project method, } \\
\text { - core curriculum that is relevant to life, } \\
\text { - school free of political ideologies, } \\
\text { - school is supposed to serve the role of a cultural } \\
\text { centre for the local community, } \\
\text { - school should take into account differences and } \\
\text { individual talents, } \\
\text { - teaching processes should be individualised and } \\
\text { personalised, taking into account the different } \\
\text { ways and pace of achieving the intended results, } \\
\text { and the requirement to set aside time for indi- } \\
\text { vidual meetings, }\end{array}$ \\
\hline
\end{tabular}




\begin{tabular}{|c|c|}
\hline $\begin{array}{l}\text { - teaching "for exams," knowledge without skills, } \\
\text { learning by heart, schematic, unified, without } \\
\text { application to real-life problems, } \\
\text { - creates competition in a negative sense, a "rat } \\
\text { race" due to too much emphasis on grades, } \\
\text { - classes are too numerous, } \\
\text { - evaluation, which is a part of the oversight sys- } \\
\text { tem is used to detect errors and deviations from } \\
\text { the model, } \\
\text { - the emphasis on oversight causes stress, fear and } \\
\text { helplessness, thus blocking learning and devel- } \\
\text { opment, } \\
\text { - grade system promotes competition ("rat race"), } \\
\text { - it divides students into good and weak ones. } \\
\text { Competition does not encourage cooperation } \\
\text { and teamwork. }\end{array}$ & $\begin{array}{l}\text { - problem and block education, } \\
\text { - reducing the number of students in a group to } 13 \\
\text { so that there is space to establish student -teach- } \\
\text { er and student-student relationships, } \\
\text { - flexible division of students into groups that } \\
\text { would learn selected subject modules, } \\
\text { - bilingual class starting from } 4 \text { th grade, } \\
\text { - soft skills classes starting from 1st grade, } \\
\text { - does not label students, does not divide them } \\
\text { into categories, does not create rankings. Thus, } \\
\text { it encourages cooperation, joint search for solu- } \\
\text { tions and sharing of experience. Trust is a condi- } \\
\text { tion for development and real learning, } \\
\text { - an introductory interview instead of an exam, } \\
\text { - teaching students to think, } \\
\text { - no homework. }\end{array}$ \\
\hline
\end{tabular}

Source: Compiled based on materials from Narada obywatelska o edukacji, 2019: 18-28

1) A key role in the education system is played by teachers who pass on knowledge (Fig. 1) This should be accompanied by raising the level of competence and skills to use advanced technology and IT tools professionally.

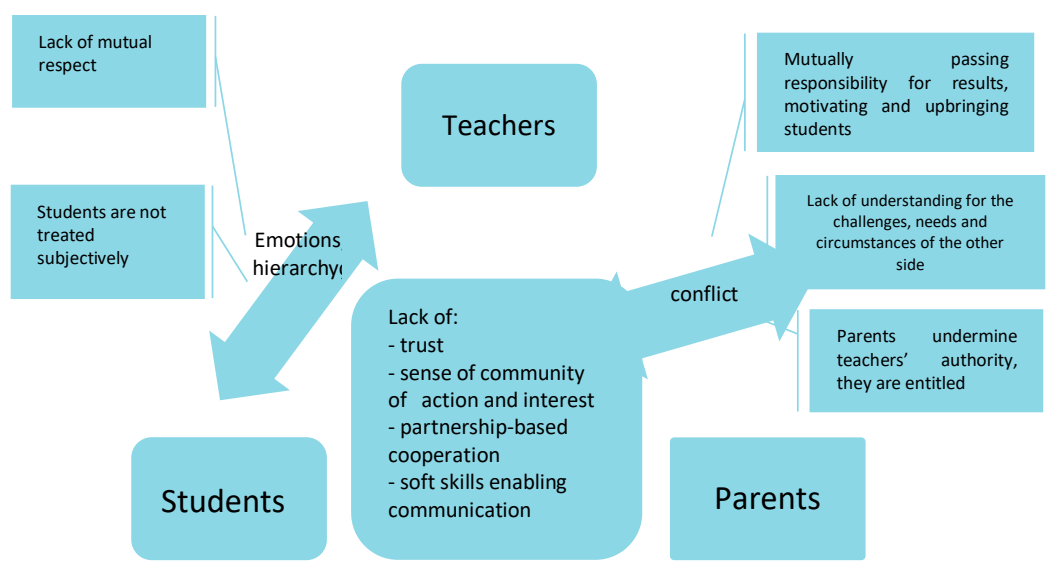

Fig. 1. Different relations - different challenges

Source: Narada obywatelska o edukacji, 2019: 18-28

Learning should be the essence and meaning of the school. On the other hand, skills and attitudes are developed and shaped by practical action of the teacher, whereas the mistakes and errors made (which is inevitable in action) allow to draw conclusions and verify the assumptions made previously. Such a learning process 
supported by the teacher can develop the student and motivate them to take further action.

The task of education for safety is to disseminate knowledge about the safety of the citizens in their local environment. The school can be a heart of local life, a place where people like to stay outside of class hours, where the local communities meet. It should also establish cooperation with the local community (families, entrepreneurs, institutions), where initiatives are taken to integrate the community and where skills and knowledge are shared.

This makes for a good time to experiment and exercise behaviour during floods, earthquakes, failure of electricity or water supply, as well as to go out of school. The school environment - work organisation, decision-making, equipment - is also very important in this regard.

Local governments are the governing bodies responsible for running schools, but their influence on school management is very limited in reality. The educational budget depends to a large extent on the amount of the educational subsidy that local governments receive from the state budget. All substantive issues, including the assignment of teacher duties, are controlled by superintendents.

Teachers' salaries and, to a large extent, the scope of duties are based on the Teacher's Charter. Therefore, it is difficult to pursue a local education policy. However, teachers undoubtedly help to develop students' passions, civic activity, and contribute to the teaching process for which respect is due. Teachers' skills and behaviour are the basis of their authority among students (Fig. 2).

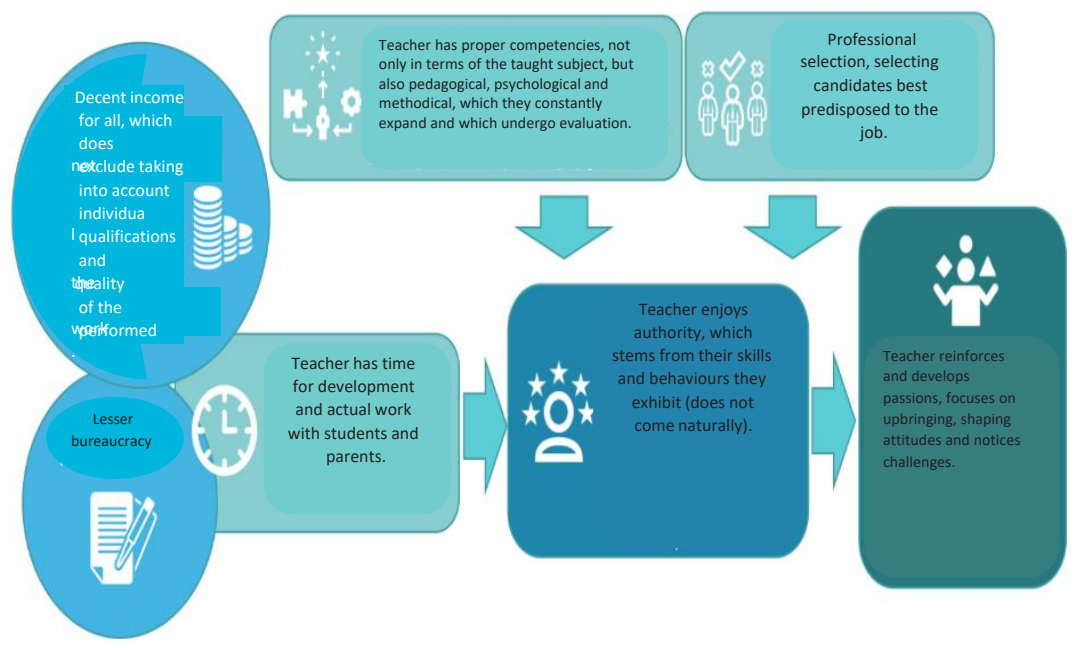

Fig. 2. Teacher's environment

Source: Narada obywatelska o edukacji, 2019: 18-28 
The core curriculum (Fig. 3) is commonly considered to be overloaded and overburdened, thus preventing the school from preparing students for life. It is also too rigid and prevents making education truly individual. The overloading of the core curriculum with content that cannot be taught makes teachers unable to keep up with the pace of teaching, while students have to catch up at home by doing homework (Raport $z$ Narad Obywatelskich, 2019: 33).

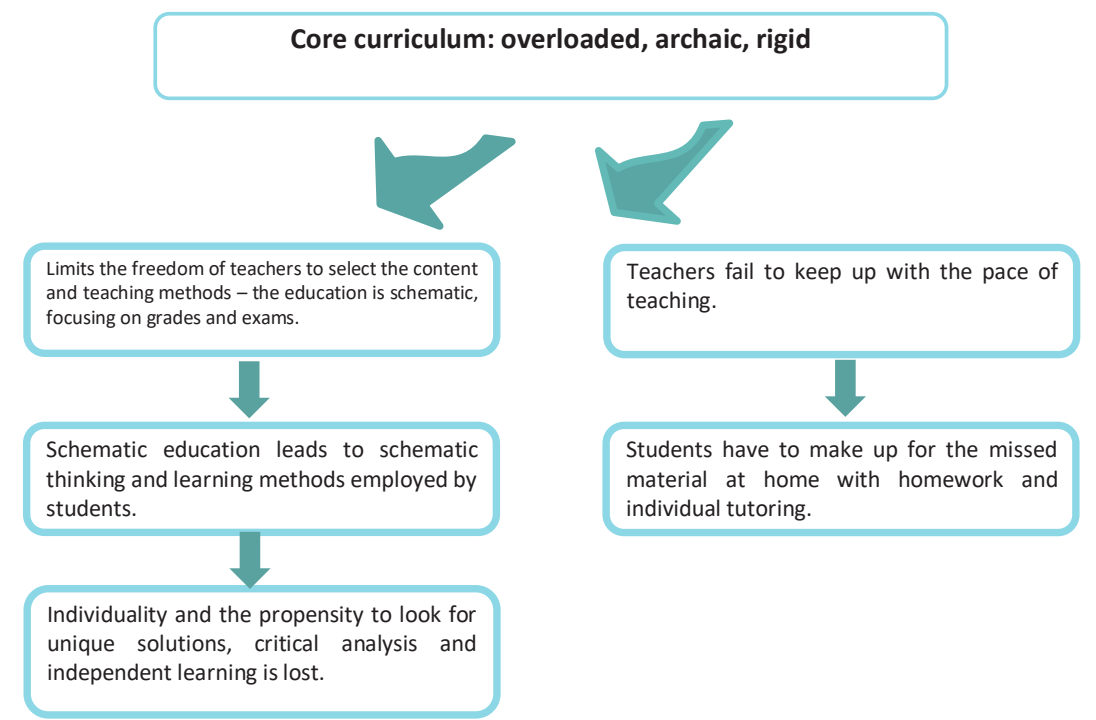

Fig. 3. Deficiencies of the core curriculum

Source: Narada obywatelska o edukacji, 2019: 18-28

\section{Comenius' principles - selected issues}

John Amos Comenius proposes universal solutions, which are worthwhile to bring up, in particular regarding changes in education. Particularly seeing how this topic remains current, even though the work was created centuries ago. On its basis, a proposal for several changes in the methods of teaching education for safety was made.

The philosopher compares the teacher to a doctor who is always prepared for the class, along with supporting materials, tools and books, etc. (Komensky, 1633: 75). He points out that theory should be ahead of practice. Practical safety education classes are rare, and comprise mostly first aid exercises. In order to improve the method of teaching this subject it is necessary to: (Komensky, 1633:76) 
1) Adapt the content to the age of the student in order to enable the application of the knowledge in practice,

2) Work on the ability to present a given activity in theory, for example basic first aid;

3) Consider performing the activity repeatedly during the training phase to make sure that the trainee will use this knowledge in their life, for example the sequence of donning protective clothing against contamination;

4) Teach topics that are relevant to life, such as personal hygiene;

5) Pay attention to the obviousness of human behaviour resulting from human nature, such as the desire to live, discovery of an unexploded ordnance.

\section{Conclusions}

Safety is and will be associated with an existing threat. Many of these threats result from human activity, from lack of knowledge and experience, from incompetence, from clumsiness. Education is a form of social contract that involves many institutions and communities and should be developed together.

Public school has the potential to integrate the local community, but also to inform, educate and activate it. It should be emphasised that every person has enough time to gain as much knowledge as they need and are expected to gain; the person who does not seek knowledge, relishes in ignorance and is responsible for it. (Locke, 1955: 119-125). In other words, everyone is able to achieve a certain level of mental development.

The eagerness to learn is based on a free will, something that cannot be forced. Nevertheless, the student should be supported. The most important element of the human ideal, according to John Locke, is reason, and the ability to use reason properly.

To be a reasonable person means controlling oneself, being prudent, critical, and able to assess the situation properly. These traits are necessary to be able to exercise freedom without endangering other people and social order (Grabowska, 2011: 243). Such an objective should guide schools and institutions that help build common security.

Teachers should have a chance to decide on the direction of education and introduce their own ideas into the process of its development.

The state may modify the structure of the core curriculum, as well as introduce changes in the system of teacher education as part of practical preparation and training. 
The government has no exclusive right to create an education system. Many positive changes can be made locally. It is worth learning from others and exchanging good practices horizontally (between local governments, teaching community, as well as schools of different types). Creating a sustainable cooperation mechanism is a challenge for institutions and communities involved in 21st century education.

A person (student) who believes in their strength, who are confident in their abilities and capable of self-control has no reason to fear freedom and accept compulsion. This fact should be taken into account when designing social institutions.

\section{Bibliography}

Doroszewski W. (2009), Słownik języka polskiego, https://sjp.pwn.pl, accessed: 7.04.2020.

Jakubczak R. (2006), Bezpieczeństwo narodowe Polski w XXI wieku. Wyzwania i strategie, Warszawa.

Kant I. (2005), Rozprawy z filozofii historii, http://www.bibliotekacyfrowa.pl/Content/32192/0003. pdf, accessed: 7.04.2020.

Kmita A. (1991), Lęk w szkole, Życie Szkoły, 5 (91).

Knopka J. (2009), Integracja europejska a lokalność", Acta Pomerania, 2, http://www.pomeraniachojnice.edu.pl/wp-content/uploads/rozne/Acta_nr2-tekst.pdf, accessed: 7.04.2020.

Komenski J.A. (1633), Wielka dydaktyka, http://www.literatura.hg.pl/komenski.htm, accessed: 7.04.2020.

Kupś T. (2005), Idem. Rozprawy z filozofii historii, Kęty.

Locke J. (1955), Rozważania dotyczące rozumu ludzkiego, O ideałach w ogólności i ich pochodzeniu, II, pp. 119-125, http://hamlet.edu.pl/locke-epistemologia, accessed: 7.04.2020.

Locke J. (1959), Myśli o wychowaniu, Wrocław-Kraków.

Narada obywatelska o edukacji (2019), Raport z Narad Obywatelskich o Edukacji, https://www. naradaobywatelska.pl, accessed: 7.04.2020.

National Security Bureau (2014), Strategia Bezpieczeństwa Narodowego, https://www.bbn.gov.pl/ftp/ SBN\%20RP.pdf, accessed: 7.04.2020.

Pieczywok A. (2011), Wybrane problemy z zakresu edukacji dla bezpieczeństwa. Konteksty - zagrożenia - wyzwania, Warszawa.

Szubrycht T. (2016), Współczesne aspekty bezpieczeństwa państwa, Zeszyty Naukowe Akademii Marynarki Wojennej, vol. 47, no. 4 (167).

Szymaniec P. (2009), Państwo i prawo w filozofii dziejów Immanuela Kanta. Wrocław

Żelazna J. (2011), Filozofia XVII w. Twórcy problemy, kontynuacje, Toruń. 
